\title{
Reflecting on the two-way educational exchange between Korea and the United States ${ }^{1}$
}

- Dr. Jae-won Lee

Korea's visibility in the United States seems noticeably increasing these years. All around, we see Hyundai Sonatas more often than in previous years. An increasing number of people seem to be carrying cell phones and other gadgets from Samsung and LG. However, some people seem to fail to connect such items to Korea, much as we don't necessarily think of "British" when we fill up our gas tanks at the BP stations.

A while back, I was sending a small parcel item to my parents in Korea at a post office branch. I said "South Korea," but apparently the U.S. Postal Service chart listed two Koreas under their cumbersome official names: Republic of Korea (ROK) and the Democratic People's Republic of Korea (DPRK). The staff person said South Korea must be the DPRK because it has the word Democratic!

Well, this puzzling experience happened in the City of Cleveland proper, where more than half the public high-school students fail to graduate. If so, then it's not that puzzling, I thought. Further, the memories of the Korean War appear to be indelible in the minds of the U.S. public. But the reality is: Korea is now one of the world's rapidly advancing countries. Korea's new President Lee Myung-bak, in his Feb. 25 (2008) inaugural address, declared South Korea is "among the 10 largest economies in the world."

1 A paper presented as a talk to the Center for Asian and Pacific Studies, University of Oregon, in Eugene, Oregon, on April 10, 2008.

(C) 2011 Kathmandu University, Nepal 
Before examining the subject of educational exchange, let's for a moment look at Korea's arts and cultural exchange. On this front, Korea is doing very well and very aggressively, often using its new wealth strategically. Colleges and universities, together with other cultural organizations, pursue numerous outreach and exchange programs with a number of other countries. Asian arts used to mean mainly the Chinese and Japanese origins. But the modern Korea today takes pride in displaying its heritage and cultural accomplishment worldwide.

In recent years, Korea's popular culture has also scored an amazing level of popularity in the unlikely territories of Japan and China under the name of "Hallyu" or "Korean Wave." Not yet a Nouvelle Vague, but it's like the popularity of Latin America's telenovelas.

The Korea Foundation, a Korean counterpart to the highly effective Japan Foundation, is a case in point. It advances Korea's arts, music, drama, literature, other humanities areas and the Korean studies to a global stage. And the exchanges here are definitely two ways; for the high volume of comings and goings, cultural venues in Korea often get fully booked well in advance. Consider this mild irritation felt by the worldfamous New York Philharmonic late in February (2008) in Seoul. After its much-publicized Pyongyang concert, the orchestra intended to give a parallel concert in Seoul on a date of its choosing, during the usual evening hours at a nice concert hall. It couldn't find an empty hall on a short notice. It ended up giving a matinée.

Being not a paid publicist of the Korea Foundation, I also peek into the other side of the coin-the dysfunctional aspect in this Korean cultural advance. Some supporters and promoters of the Korean arts and culture sometimes cross the line of balance in touting the "beauty" and "exquisiteness" of the Korean cultural heritage. When they dwell on the fete of the $13^{\text {th }}$ century Koreans in inventing the metal types for printing, even before Guttenberg, they overlook the harsh factual reality of the 
$19^{\text {th }}$-century hermit kingdom (1392-1910) importing the metal types from Japan to launch its newspaper printing.

Koreana, the quarterly publication of the Korea Foundation, often carries articles on the Korean culinary arts, not so subtly claiming that only Koreans can prepare and create such "esoteric" food to perfection. Probably so because it's the Korean food, but, to be realistic, the best food to a person is his or her native food, the tastes of which one acquires from infant learning, as William Marling aptly observes in his 2006 book on 'How 'American' Is Globalization?' - which, by the way, suggests an antithesis to Thomas Friedman's "flat" world (2005).

The Autumn 2007 issue of Koreana prints a feature section on Hangeul, the Korean alphabet. One article suggests that, Hangeul being a writing system of "systematic and rational structure," it has "potential to serve as an international writing system that might help to bring the world closer together" (Kim, 2007). In this ego-ridden climate, there's no room for reflection on the virtue of, for instance, Kemal Pasha's Turkish language reform. You would recall that this Turkish statesman replaced the Ottoman language's Arabic script with a variant of the Latin alphabet, with the American educator John Dewey's encouragement. And another article in the series audaciously declares Hangeul be the "world's greatest writing system," by quoting a German linguist who praises Hangeul's "philosophical principles and scientific theories" (Lee, 2007, citing Werner Sasse).

Here we see an example of external experts on Korean studies merely validating a tunnel vision that prevails in the Korea proper. Or could it be merely a case of the general tendency where highly specialized scholars often hold onto an ultimate true belief in the worth of their chosen fields, something like a scholar studying the mating behavior of a tiny insect believing as if it holds the key to a perpetual prosperity of the human 
race? The lamp has its blind spot right under its base - so goes a Korean saying.

Today, here is my first point of observation. That is, Korea's arts and cultural exchange, for it to be a genuine two-way exchange, needs input and stimulation from outside that include critical eyes, innovative perspectives and alternative viewpoints, not just another cheering squad.

I am tempted to mention a couple of pertinent examples. How about the late Prof. Edward Wagner of Harvard University? His seminal study of Joseon (Lee) Dynasty's rosters of its highest-level civil-service examination still sheds lights on the Korean society's exclusive hereditary social structure and the aristocratic elite class (Song, 2000). Prof. Bruce Cumings of the University of Chicago could be another apt example. His study on the origins of the Korean War helps us see the broader and contextual factors beyond the manifest occurrence in examining the meaning of the conflict (Cumings, 1981). Here I have to quickly add that many revisionist scholars in Korea have been stretching his basic thesis to their own ideological advantages in a far-fetched manner.

Now, let's turn to the arena of educational exchange - the exchange of students - between the two countries. Actually, it's a lopsided one-way traffic, with a very small number of American students heading for South Korea while a very large number of Korean students coming to the United States.

Only about 1,300 U.S. students went to Korea under their study-abroad programs during the Academic Year 2005-06, according to the latest available statistics from the Open Doors 2007 report of the Institute of International Education. And how many Korean students in the United States? Believe it or not, it's a staggering number: 103,400 in all, as of January this year (2008), according to the Student and Exchange Visitor Information System (SEVIS) of the U.S. Department of Homeland Security. This system reports that South Korea is 
the country with the highest number of active students in the United States. The next four countries, in order, are: India with 88,100 students; China, 72,200; Japan, 41,900; and Taiwan, 32,900 (see the SEVIS database).

In 1967 when I came to this country as a student, the entire foreign students in the United States numbered only 110,000. Now, such a number of students are coming from South Korea alone.

For some demographic features of the Korean students, we need to go back to the IIE statistics; this IIE data set focuses on college-level students. According to this IIE data set for the AY 2006-07, South Korea ranks third as the top place of student origins, where India leads with 83,800 students; China, 67,700; South Korea, 62,400; Japan, 35,300; and Taiwan, 29,000 (IIE, 2007). South Korea has remained among the Top 5 countries ever since 1984-85. Considering the size of South Korea's population, only about 50 million, we can safely assume that South Korea's representation might have been No. 1 all along in the proportional terms per population unit. Besides the degree-seeking students, South Korea had additional representations in 2006: about 10,000 Koreans taking various intensive English programs and another 9,300 staying as visiting scholars.

In the absence of any reliable tabulation, let's suppose that about two-thirds of all the South Korean students eventually return home after completing their degree work in the United States. And there are such large numbers of ESL students and visiting scholars annually, all these returning home, in principle. Then South Korea could be overflowing with all this U.S.-educated high-caliber workforce. In fact, various sectors of South Korea are saturated with U.S.-trained nationals in important positions, starting from the Korean Government Cabinet and the Presidential Secretariat to colleges' and universities' faculty of most disciplines. 
Given this picture, one would assume that many Koreans, if not all, would command English fairly competently and that many well-educated Koreans would entertain balanced and perceptive views of the U.S. culture and society.

Well, to say the least, the two assumptions above remain as a wishful thinking at best in today's Korea. Korea's globally oriented and export-driven economy surely demands competency in the language of trade, English, but this foreign language remains a perennial headache to the Koreans at large. They attribute this chronic problem to the grammar-centered instruction of English at schools.

President Lee, during his election campaign, declared a sort of "war on English" by wondering aloud why high-school students can't speak in English after years of English lessons. He even ventured to suggest that perhaps English be the exclusive language of classroom instruction for all subjects at schools.

Did he mean that even the Korean language ought to be taught in English? That's the way the all-powerful teachers' union took his suggestion. Child psychologists jumped in by arguing that a national identity is best fostered in the native language in the minds of the rising generation. And, of course, a host of opposition groups decried that he is preparing the death bed for the Korean language, the "most scientific language in the world," the language of "nuances and beauty."

Politics just nipped the bud of some soul-searching discourse needed on an issue that most Koreans admit it is an issue. Many Korean parents are getting tired of sending their kids, by spending a fortune, to private tutoring places of Englishlanguage classes. In this climate, the spirit of the age being as such, there's a growing national consensus in Korea that something drastic and definitive should be done with their English as a societal priority. 
Colleges and universities are struggling to introduce more courses taught in English. But they all bemoan the reality that they don't have a sufficient number of instructors who can competently conduct the classroom instruction in English.

We have to wonder where the large number of U.S.-educated Ph.D.s are. Actually, they are right on their faculty, oftentimes as leading members of the faculty, but apparently they are not functioning as a productive building bloc of this national agenda of what they call "English question."

Speaking of the role of the U.S.-educated intellectuals in Korea, I have another lingering question or mystery. That is, in South Korea now, quite a few people entertain a fairly high degree of anti-American sentiment, often based on limited, distorted or erroneous information on this country. The voices of this sector are louder but the large number of U.S.-educated people, who, I should presume, would know it better, tends to remain reticent.

Of course, the U.S. image problem abroad is not a onedimensional issue; there are many factors of complexity working in tandem - the war in Iraq, the unilateral tendency in the Neoconservative policy implementations, trade disputes, global warming, handling of North Korea, to name just a few as often reported by the Pew Research Center's Global Attitudes Project (see the database at http://pewglobal.org/).

Granted that's the complexity of the issue, how should we take some of the recent poll results regarding Korean attitudes toward the United States? By a ratio of $56 \%$ to $44 \%$, Koreans oppose U.S. military intervention in global conflicts, according to a 2004 poll conducted by the Chicago Council on Foreign Relations (see the database at http://thechicagocouncil.org/). Yet, in the same poll, 64\% of Koreans favor, with $31 \%$ objecting to, the U.S. military joining in reversing aggression by North Korea if this happens. They hate the cake while desiring it when hungry. 
A former superintendent of the Korea Military Academy recently revealed that 34\%, the largest percentage, of his 2004 freshman class named the United States as the "main enemy state of South Korea." Those novice cadets who singled out North Korea as South Korea's primary hostile state were 33\% (Yu, 2008). By the way, that particular freshman class graduated a month ago, on March 11, this year (2008), and as commissioned officers they now serve in the Korean Army side by side with the 30,000 American soldiers who are stationed on the Korean peninsula.

In so many words thus far, I have belabored some of the Korean domestic issues in order to make the point that there is definitely something missing in the character and quality of U.S. education for some foreign students like those from Korea.

America's doctoral programs in general do not differentiate their curriculum for foreign students; their requirements are largely one-size-fits-all standardized sets. If there are differentiations, they are in the microscopic specializations per discipline. Doctoral students in particular follow Thomas Kuhn's normal-science route where measurable hypotheses drawn from the prevailing paradigms are tested quantitatively by the use of analytic computer programs (Kuhn, 1970).

In this process, English is a necessary evil at best; it's what the foreign students need to bear with in order to merely complete the dissertation writing.

And, as to their life in this land of diversity, their experience in America is largely from the limited window of their campus towns. Please imagine the kind of image of America the foreign students would carry back to their home countries after living in the New England environment of Boston. Students from Midwestern towns and Southern campuses would have much different experiences in this same country. 
Therefore, as for the students from Korea, for instance, if our doctoral programs provide opportunities to improve on their English competency as well as a few courses to take in American studies, I feel certain that they will benefit immensely in their future professional careers, be it back in Korea or in this country.

Doctoral candidates are usually stressed by shortage of time and they are driven solely by determination to complete the narrowly defined line of specialty in a single-minded manner. If the courses on English and American studies are made a requirement to take without the fear of penalty, like auditing, who knows many actually would enjoy having such opportunities. One may see it as an American general education.

This way, life will get richer and the key word "philosophy" in their terminal degree Ph.D. would carry some value-added meanings. I may be dreaming too much, but, for instance, those who study poverty in a sociology doctoral program could get something relevant from reading William Faulkner's novels or Arthur Miller's plays. Engineering doctoral students could enjoy reading about the American Whig Party's "Internal Improvement" plan. Those studying pop culture could see, beyond the silly plays on the television screen, something entirely different in Van Cliburn's Tchaikovsky or Beverly Sills' opera singing. In my own field of communication studies, some of those studying political communication would find the 1858 Lincoln-Douglas debates refreshingly instructive.

Foreign-born doctoral students, when they return home, could become, in effect, very rewarding agents of America's public diplomacy in substantive terms. After all, the U.S. public and private sectors, together with the colleges and universities, subsidize $37 \%$ of the cost of foreign students' education at the doctoral level. Earlier, we said the educational exchange between South Korea and the United States is bound to be a one-way flow. The students returning home could make the 
flow an enriched two-way exchange if they carry with them some deeper appreciation of what America has been like than the snapshot of what it looks like now at a glance.

I would like to close my observation today by citing a case in point from President Lee's inaugural address. I expected some fluency in its English text for the president's special concern about English and for the fact that he is surrounded by many U.S.-educated senior staff advisers. While beginning reading the opening paragraph, I had to grab the red pen, an occupational habit of a journalism teacher. By the sixth paragraph, I realized that it's more than a copyediting problem, a problem with the literal translation of the president's message.

If you are a nit-picking Freshman English instructor, the indiscriminate use of the past tense may also bother you in the following quote of the sixth and seventh paragraphs in the address (Lee, 2008):

This year marks the $60^{\text {th }}$ anniversary of the founding of the Republic of Korea. We fought for and regained our land that was taken from us and established our nation. We gave our best to our day's work.

As a result, our great nation achieved what no other nation ever achieved in history. In the shortest period of time, this nation achieved both industrialization and democratization. Never before seen in human history, we achieved all this with only our own fierce determination and sheer fortitude.

Granted the inauguration of a new president is often a place of some morale boosting and bragging, yet a little bit of qualifying expressions here and there could have made the sweeping claims of Koreans' accomplishment sound somewhat more dignified. Koreans love to say they value modesty and 
humility, same as saying some of you Americans tend to have "big mouths."

On the inauguration stand on that day (Feb. 25, 2008), U.S. Secretary of State Condoleezza Rice dutifully sat in the dignitaries' corner. I wondered what she could have been thinking at that point. "Wow, did the Koreans themselves end the Second World War? How about the 40,000 American soldiers who paid their ultimate sacrifice for these Koreans to be where they are today, not under Dear Leader Kim Jong-il's loving care?"

But I am certain she stayed a polite guest there by recalling, for instance, $\mathrm{Al}$ Gore's alleged wild claim of inventing the Internet. After all, her own boss, President Bush, always declares that the state of the Union is invariably great.

Thank you very much for listening to me today.

\section{References}

Cumings, B. (1981). The origins of the Korean War, Vol. 1. Princeton, NJ: Princeton University Press.

Friedman, T. L. (2005). The world is flat. New York: Farrar, Straus and Giroux.

Institute of International Education (2007). Open doors 2007:

Report on international educational exchange. New York: IIE.

Kim, J. (2007). Can Hangeul help to bring the world closer together? Koreana, 21 (Fall). Retrieved from http://koreana.kf.or.kr

Kuhn, T. S. (1970). The structure of scientific revolutions $\left(2^{\text {nd }}\right.$ ed.). Chicago: University of Chicago Press.

Lee, M. B. (2008, Feb. 25). Inaugural address. Retrived from http://www.president.go.kr 
Lee, S. G. (2007). The world's preeminent writing system. Koreana, $21 \quad$ (Fall). $\quad$ Retrieved from http://koreana.kf.or.kr

Marling, W. (2006). How "American" is globalization? Baltimore, MD: Johns Hopkins University Press.

Song, J., \& Wagner, E. W. (2000). Boju Joseon mungwa bangmok, CD-ROM. Seoul: Dongbang Midieo.

Student and Exchange Visitor Information System (SEVIS), U.S. Department of Homeland Security (http://www.ice.gov/sevis/).

$\mathrm{Yu}$, S. (2008, April 4). South Korea's main enemy states as viewed by the 2004 freshman class of the Korea Military Academy. The Chosun Ilbo. Retrieved from http://bemil.chosun.com

The author is a Professor Emeritus and former Director of the Division of Journalism and Promotional Communication at Cleveland State University in Cleveland, Ohio. He was a Fulbright visitor to the Dept. of Langauges and Mass Communication, Kathmandu University, during June-August 2008. 